OPEN ACCESS

Edited by:

Joseph C. Sun,

Memorial Sloan-Kettering Cancer

Center, USA

Reviewed by:

Bojan Polić

University of Rijeka, Croatia

Francesco Colucci,

University of Cambridge, UK

${ }^{*}$ Correspondence:

Siok-Keen Tey

siok.tey@qimrberghofer.edu.au

Specialty section:

This article was submitted to

NK Cell Biology,

a section of the journal

Frontiers in Immunology

Received: 02 February 2016 Accepted: 01 April 2016

Published: 15 April 2016

Citation:

Ullah MA, Hill GR and Tey SK (2016) Functional Reconstitution of Natural

Killer Cells in Allogeneic

Hematopoietic Stem Cell

Transplantation.

Front. Immunol. 7:144.

doi: 10.3389/fimmu.2016.00144

\section{Functional Reconstitution of Natural Killer Cells in Allogeneic Hematopoietic Stem Cell Transplantation}

\author{
Md Ashik Ullah ${ }^{1}$, Geoffrey R. Hill ${ }^{1,2}$ and Siok-Keen Tey ${ }^{1,2,3 *}$
}

${ }^{1}$ Bone Marrow Transplant Laboratory, QIMR Berghofer Medical Research Institute, Brisbane, QLD, Australia, ${ }^{2}$ Department of Haematology and Bone Marrow Transplantation, Royal Brisbane and Women's Hospital, Brisbane, QLD, Australia, ${ }^{3}$ School of Medicine, University of Queensland, Herston, QLD, Australia

Natural killer (NK) cells are the first lymphocyte population to reconstitute following allogeneic hematopoietic stem cell transplantation (HSCT) and are important in mediating immunity against both leukemia and pathogens. Although NK cell numbers generally reconstitute within a month, the acquisition of mature NK cell phenotype and full functional competency can take 6 months or more, and is influenced by graft composition, concurrent pharmacologic immunosuppression, graft-versus-host disease, and other clinical factors. In addition, cytomegalovirus infection and reactivation have a dominant effect on NK cell memory imprinting following allogeneic HSCT just as it does in healthy individuals. Our understanding of NK cell education and licensing has evolved in the years since the "missing self" hypothesis for NK-mediated graft-versus-leukemia effect was first put forward. For example, we now know that NK cell "re-education" can occur, and that unlicensed NK cells can be more protective than licensed NK cells in certain settings, thus raising new questions about how best to harness graft-versus-leukemia effect. Here, we review current understanding of the functional reconstitution of NK cells and NK cell education following allogeneic HSCT, highlighting a conceptual framework for future research.

\section{Keywords: NK cell, allogeneic HSCT, NK cell education, memory NK cell, cytomegalovirus}

\section{BACKGROUND}

Allogeneic hematopoietic stem cell transplantation (HSCT) can be curative of otherwise incurable leukemia through its ability to mediate an immunological graft-versus-leukemia effect. Its main limitations are graft-versus-host disease (GVHD), infections, and leukemia relapse, all of which are critically dependent on immune reconstitution. Natural killer (NK) cells are well-established mediators of anti-leukemic and anti-viral responses (1). Donor NK cells can also attenuate GVHD, possibly by lysing alloreactive donor $\mathrm{T}$ cells and recipient antigen-presenting cells $(2-5)$. There is much interest surrounding the importance or otherwise of NK cells on clinical outcome, particularly in regard to NK cell-mediated GVL effects (5-8). In this review, we will present the current state of knowledge on the functional reconstitution of NK cells to provide a framework to the debate. 


\section{KINETICS OF NK CELL RECONSTITUTION}

Natural Killer cells are the first donor-derived lymphocyte population to reconstitute numerically following allogeneic HSCT. Normal NK cell numbers are generally observed within the first month post-transplant irrespective of the graft source: bone marrow (9), granulocyte colony-stimulating factor (G-CSF)mobilized peripheral blood stem cell (PBSC) (9-11), or umbilical cord blood (12-14). It is generally thought that the reconstituting NK cells are primarily derived from the differentiation and maturation of progenitor cells rather than the expansion of mature NK cells within the graft. This concept is supported by two observations. First, the rate of NK cell reconstitution is largely independent of the type of graft and its NK cell content: side-byside comparisons have found similar reconstitution kinetics following unmanipulated PBSC transplant, CD34 $4^{+}$selected PBSC transplant, and bone marrow transplant despite log-fold differences in NK cell content (median $20-70 \times 10^{6} / \mathrm{kg}, 0.2-0.7 \times 10^{6} \%$ $\mathrm{kg}$, and $5-7 \times 10^{6} / \mathrm{kg}$, respectively) $(9,15-17)$, Second, the early reconstituting $\mathrm{NK}$ cells have an immature $\mathrm{CD} 56^{\text {bright }}$ phenotype and do not acquire the predominantly CD $56^{\mathrm{dim}}$ donor NK phenotype for several months (17-19). Although NK cell development from progenitors is likely dominant, the in vivo expansion of transferred NK cells can also contribute. In a comparison of two different methods of T-cell depletion (CD3/CD19-depletion versus $\mathrm{CD} 34$-selection), $\mathrm{NK}$ cell reconstitution and acquisition of mature NK cell phenotype were more rapid in recipients of CD3/CD19-depleted grafts, which contained 3-log more mature NK cells than CD34-selected grafts (20). The impact of T cells on NK cell reconstitution is difficult to cleanly define as it is also linked to the use of post-graft immunosuppressive therapy. In haploidentical transplantation using extensively T-cell-depleted graft without post-transplant immunosuppression, NK cell reconstitution is particularly brisk (8) but in other settings where cyclosporine-based immunosuppression is used in both T-cell-deplete and T-cell-replete arms, the reconstitution of NK cell numbers was generally found to be similar between the groups $(15,17,18)$.

\section{ACQUISITION OF NK CELL FUNCTIONALITY}

Although NK cells reconstitute numbers by around 1 month posttransplant, they take several months to acquire the immunophenotypic and functional characteristics found in healthy donors. CD56 ${ }^{\text {bright }} \mathrm{NK}$ cells, which are the precursors of CD56 $6^{\text {dim }} \mathrm{NK}$ cells (21), account for $40-50 \%$ of the NK cells in the first 3 months post-transplant as compared to only $5-10 \%$ in healthy donors $(17,19,22-25)$. These early reconstituting NK cells also express higher levels of the inhibitory receptor, NKG2A, at around $90 \%$ compared to around $50 \%$ in healthy donors $(17,22-25)$. During NK maturation, the CD56 ${ }^{\mathrm{dim}} \mathrm{NK}$ cells lose NKG2A expression and express the activating NKG2C receptor, killer cell inhibitory immunoglobulin-like receptors (KIRs), and $\operatorname{CD} 57(26,27)$. The acquisition of full donor surface phenotype takes 3-6 months, sometimes longer $(17,24-26,28)$. Full NK cell functionality is similarly not achieved for at least 6 months post-transplant
$(17,24,29)$. In healthy individuals, CD56 ${ }^{\text {bright }} \mathrm{NK}$ cells are adapted to produce cytokines, particularly interferon- $\gamma($ IFN- $\gamma$ ) and tumor necrosis factor (TNF), whereas CD56 $6^{\text {dim }} \mathrm{NK}$ cells are enriched for perforin and granzymes, and thus adapted for cytotoxicity (30, 31). Following allogeneic HSCT, however, there is a dissociation between the recovery of cytokine production and cytotoxic function (29). Despite the high proportion of CD56 $6^{\text {bright }}$ NK cells in the first 6 months post-transplant, IFN- $\gamma$ production in response to the MHC class I-deficient K562 cell line or primary acute myeloid leukemia cells is more severely and consistently impaired than NK cell degranulation and cytotoxicity $(24,27,29)$. This somewhat contradictory finding is nonetheless consistent with the reduced expression of T-bet, a key inducer of IFN- $\gamma$ production (32), at all stages of NK cell differentiation post-transplant (27). Furthermore, NK cell expression of T-cell immunoglobulin and mucin-containing domain-3 (Tim-3) is also lower posttransplant (33). In healthy individuals, Tim-3 is expressed on nearly all mature CD56 ${ }^{\text {dim }} \mathrm{NK}$ cells and a majority of immature CD56 ${ }^{\text {bright }} \mathrm{NK}$ cells $(33,34)$. It is upregulated by IL-15 or IL-12 and IL-18 in vitro $(33,34)$, and has been shown to both enhance IFN- $\gamma$ secretion (33) and suppress cytotoxicity (34). As the level of Tim-3 expression at 3-6 months post-transplant is only half that of healthy controls, this may partly account for the discordant recovery of cytokine production and cytotoxic function (29).

The influence of graft $\mathrm{T}$ cell content on NK cell development and function is of clinical interest because the NK cell-mediated GVL effect is most evident in T-cell-depleted transplantation (5-8). While T-cell graft content does not have a significant influence on the numerical reconstitution of NK cells $(15,17$, 18), there is a general trend towards enhanced functional NK cell maturation in T-cell-replete versus T-cell-deplete transplants, which is contrary to the relative importance of NK cells in T-cell-deplete transplants. In a study comparing HLA-matched T-cell-replete transplant with immunosuppression versus HLApartially matched T-cell-deplete transplant without immunosuppression, target cell-induced IFN- $\gamma$ secretion and degranulation were relatively attenuated in the T-cell-deplete group (29). This is consistent with an earlier study by the same group that found that NK cells in partially T-cell-deplete transplants had attenuated IFN- $\gamma$ production compared to T-cell-replete transplants, with a similar proportion in both groups receiving cyclosporin A for GVHD prophylaxis (70 versus $81 \%$ ) (18). Similarly, in a study comparing partial T-cell-depleted transplant (median $54 \times 10^{4} \mathrm{~T}$ cells $/ \mathrm{kg}$ ) versus extensive T-cell-depleted transplant (median $3.7 \times 10^{4} \mathrm{~T}$ cells $/ \mathrm{kg}$ ), with neither group receiving post-transplant immunosuppressive therapy, the reconstituting NK cells in the extensively T-cell-depleted group had higher proportions of $\mathrm{CD} 56^{\text {bright }}$ and $\mathrm{NKG} \mathrm{A}^{+}$immature $\mathrm{NK}$ cells and diminished cytotoxicity, although IFN- $\gamma$ secretion was enhanced $(19,22)$. The mechanism by which T cells facilitate NK cell functional maturation is unclear: it may include the direct activation of CD56 $6^{\text {bight }} \mathrm{NK}$ cells by T cell-derived IL-2 (35), or indirectly through IL-12 and IL-18 produced by activated macrophages during acute GVHD (36), and this effect was observed irrespective of the use of post-transplant immunosuppression. It is difficult to isolate the effect of pharmaceutical immunosuppression on NK cell reconsitution because it is tightly linked to the graft 
T-cell content and subsequent risk of GVHD, both of which can influence NK cell reconstitution. Cyclosporin A does not have any impact on NK cell function in short-term cultures (37) but it has been shown to suppress the in vitro proliferation of NK cells, especially the $\mathrm{CD} 56^{\mathrm{dim}} \mathrm{CD} 16^{+} \mathrm{KIR}^{+} \mathrm{NK}$ cells, resulting in a relative increase in the number of immature $\mathrm{CD} 56^{\text {bright }} \mathrm{CD} 16^{-} \mathrm{KIR}^{-} \mathrm{NK}$ cells (38). Hence, cyclosporin A can have a direct effect on NK cells in addition to any indirect effect through modulation of GVHD although more studies, including in vivo studies, will be required.

\section{NK CELL EDUCATION FOLLOWING ALLOGENEIC HSCT}

Natural killer cells sense and respond to cellular transformation, stress, and infection via an array of germ-line encoded activating and inhibitory receptors (39). The inhibitory receptors recognizing self-MHC class I are considered the predominant mediators of self-tolerance and the engagement of these receptors with their cognate MHC during NK cell development results in "licensed" NK cells that have functional competency, whereas failure of receptor engagement results in hyporesponsiveness (40-42). In HLA-mismatched transplantation where there is a mismatch in the inhibitory KIR-ligands located on HLA-B and HLA-C loci, there is a potential for donor NK cells that are licensed through the non-shared donor HLA to recognize and attack recipient leukemic cells that lack the cognate inhibitory HLA ligand. This "missing self" NK alloreactivity can be very potent and is associated with decreased risk of relapse in T-cell-depleted haploidentical transplantation for acute myeloid leukemia $(5,6,43)$. The importance of MHC class I-mediated NK cell licensing is, however, not entirely clear-cut, particularly in allogeneic HSCT that are HLA-matched or HLA-mismatched but KIR-ligand matched. In both healthy donors and patients post-transplant, there is a hierarchy of target cell-induced NK cell degranulation response: (i) $\mathrm{NKG}_{2} \mathrm{~A}^{-} \mathrm{KIR}^{-}$and $\mathrm{NKG} 2 \mathrm{~A}^{-}$Non-self-KIR ${ }^{+} \mathrm{NK}$ cells are hyporesponsive (where non-self KIR recognizes an HLA ligand that is not expressed by the individual), (ii) NKG2 ${ }^{+} \mathrm{KIR}^{-}$ NK cells and NKG2A-Self-KIR ${ }^{+}$NK cells have similar degrees of responsiveness (where self-KIR is a KIR that recognizes a self HLA ligand), and (iii) $\mathrm{NKG}_{2} \mathrm{~A}^{+}$Self- $\mathrm{KIR}^{+} \mathrm{NK}$ cells have the highest level of responsiveness $(17,29,44)$. Hence, NKG2A have a role in NK cell education post-transplant that is additive to that of inhibitory KIRs. Since KIR expression is reduced for at least 3-6 months post-transplant (17-19, 22, 23, 44), NK cell degranulation response during this time is dominated by $\mathrm{NKG}_{2} \mathrm{~A}^{+} \mathrm{KIR}^{-}$ $\mathrm{NK}$ cells rather than $\mathrm{KIR}^{+} \mathrm{NK}$ cells (17). The extent to which these $\mathrm{NKG}_{2} \mathrm{~A}^{+} \mathrm{KIR}^{-} \mathrm{NK}$ cells can mediate GVL effect is likely context dependent. The ligand for NKG2A, HLA-E, is often expressed on leukemic cells, and its immune evasive capacity is underscored by the demonstration that antibodies against NKG2A can enhance NK cell-mediated lysis of leukemic cells both in vitro and in vivo $(22,45)$. However, not all leukemic cells express HLA-E and other studies have shown relatively low levels of HLA-E expression on primary leukemic blasts $(19,46)$ and since HLA-E is expressed in complex with a signal peptide from certain MHC class I molecules, its expression is also low in MHC class I-deficient blasts, and in this regard, the HLA-E/NKG2A interaction can be considered to be analogous to that of MHC class I/inhibitory KIRs.

Can allogeneic HSCT break NK tolerance? In the above studies, drawn from both T-cell-replete and T-cell-deplete transplants, with or without cyclosporine A, NK cell expression of at least one inhibitory receptor remained necessary for NK cell functional competency as $\mathrm{NKG}_{2 \mathrm{~A}^{-}} \mathrm{NK}$ cells that were $\mathrm{KIR}^{-}$or expressed only non-self KIR remained hyporesponsive $(17,29,44)$. There is, however, evidence that NK cell tolerance can be broken post-transplant. In one study, unlicensed NK cells that express single non-self inhibitory KIR were found to have increased cytokine secretion and cytotoxicity at 3-6 months post-transplant compared to their respective donors, and this effect was independent of NKG2A expression (47). The mechanism underpinning this is unclear but there are clues from murine models. In mice, $\mathrm{NK}$ cell function can be restored in vitro with IL-2 or IL-12 + IL-18, or strong stimulation via activating receptors $(41,48,49)$. In vivo, NK cell tolerance can be broken by infection with Listeria monocytogenes and murine cytomegalovirus (MCMV) (50-52). Indeed, NK cell activation early post MCMV infection is dependent on pro-inflammatory cytokines and independent of activating receptor ligation, and licensed and unlicensed NK cells were similarly activated and produced similar levels of IFN- $\gamma$ and granzyme B $(52,53)$. Since CMV reactivation is a common complication of allogeneic HSCT, it is possible that a similar mechanism underpinned the clinical observation. Unlicensed NK cells that break tolerance are not merely bystanders but can have specific protective function. In the MCMV model, unlicensed NK cells proliferated more robustly than licensed NK cells and were more effective in controlling MCMV infection because, unlike licensed NK cells, they were not inhibited by MHC class I expression on target cells (52). Similarly, unlicensed NK cells have been shown to be the primary mediators of antibody-dependent cell-mediated cytotoxicity during monoclonal antibody treatment for neuroblastoma (54). In HLA-matched and mismatched allogeneic HSCT, the risk of acute myeloid leukemia relapse is lower in patients who lack one or more HLA ligands to inhibitory KIRs ("missing KIR-ligand" hypothesis) $(55,56)$, which further supports the importance of unlicensed NK cells as a mediator of GVL effects (Figure 1).

Since the first reports on the protective effect of KIR-ligand mismatching on leukemia relapse more than 10 years ago $(5,57)$, our understanding of NK cell education has evolved and the "missing self" hypothesis is more complex than it initially seemed. It is now known that mature NK cells can undergo "reeducation" following transfer into a different MHC environment; thus, mature responsive NK cells from wild-type mice become hyporesponsive when transferred to MHC class I-deficient mice and vice versa $(58,59)$. Furthermore, the education process requires the MHC class I to be expressed on all or most cells, or hyporesponsiveness is dominantly induced (41); and both nonhematopoietic as well as hematopoietic cells may be involved in NK cell education $(58,60)$. These new insights suggest that recipient MHC class I-mediated NK cell education may diminish the anti-leukemic effect of "missing self" NK alloreactivity, and are consistent with the observation that alloreactive donor NK cells were detectable mainly in the first 3 months post-transplant (57). 


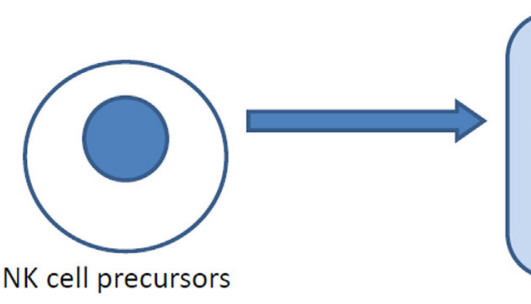

\section{BONE MARROW}

- NK cell development

- NK education

- Donor HLA

- Recipient HLA (?)

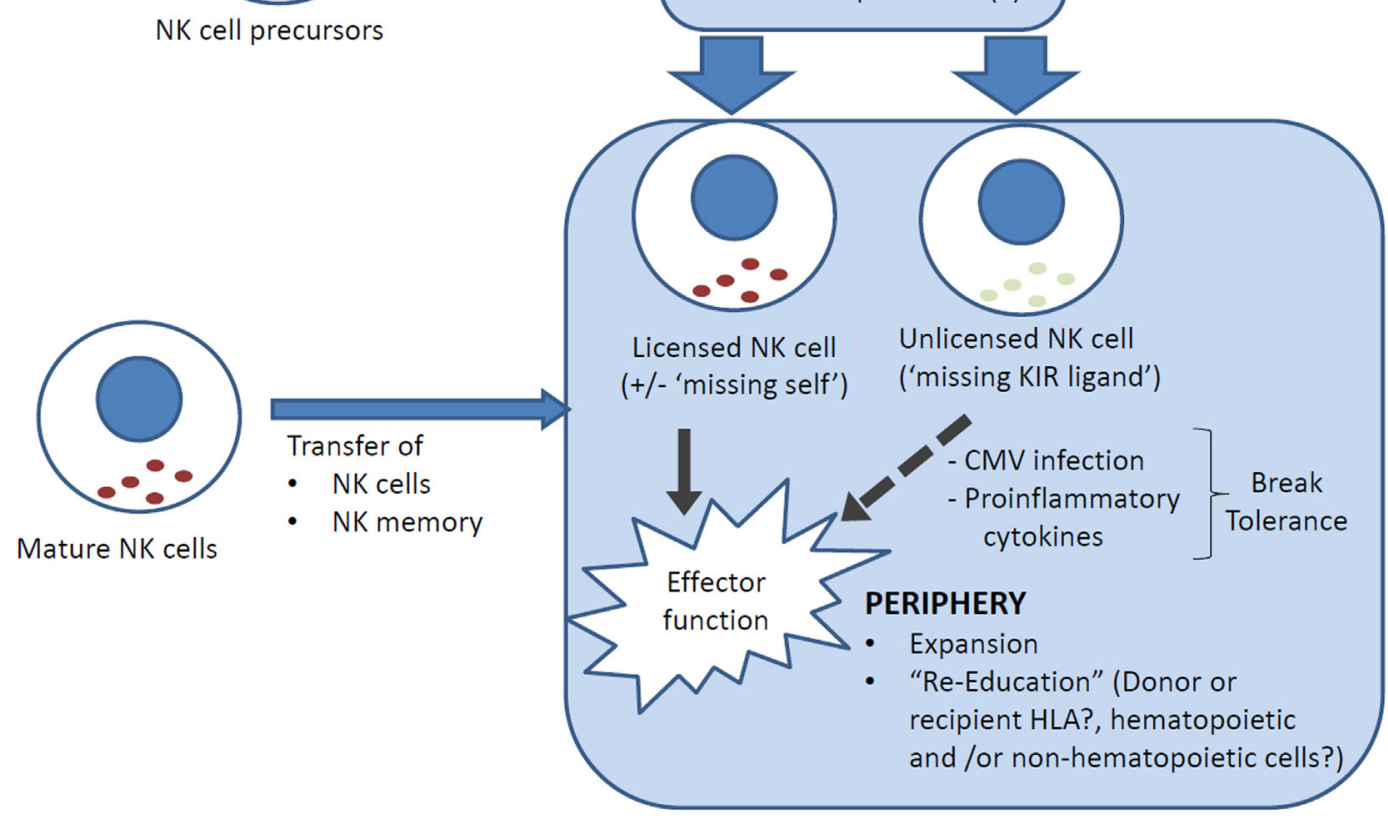

FIGURE 1 | NK cell reconstitution and education following allogeneic HSCT. Reconstituting NK cells can be derived from (i) NK cell precursors, ranging from hematopoietic stem cells through to common lymphoid progenitors, that differentiate into NK cells in the bone marrow, and (ii) transferred mature NK cells, which carry with them a mature NK phenotype and NK memory. NK cells are educated in the bone marrow but can be "re-educated" in the periphery. It is uncertain whether recipient cells (generally non-hematopoietic only post transplant) are involved in NK cell education. In HLA-mismatched transplants, NK cells that are licensed by inhibitory KIRs that recognize a ligand (HLA) that is expressed only by the donor and not the recipient may lyse recipient cells ("missing self") and contribute to the GVL effect. Conversely, an NK cell that has not encountered a cognate MHC class I for its inhibitory KIR(s) is "unlicensed" and hyporesponsive, but can acquire functional competency when stimulated by pro-inflammatory cytokines, for example, in the setting of CMV reactivation.

\section{IMPACT OF CMV ON NK RECONSTITUTION}

Cytomegalovirus reactivation is a common and life-threatening complication following allogeneic HSCT. In healthy individuals, CMV serostatus accounts for a significant proportion of the variability in NK cell immunity (61-63). Similarly, in allogeneic HSCT, CMV reactivation influences the frequency, phenotype, function, and/or repertoire of the reconstituting immune system (64-70). Interestingly, CMV reactivation is also associated with lower risks of leukemia relapse $(71,72)$, and understanding its influence on the immune landscape may provide insight into new therapeutic approaches to enhance the GVL effect.

The concept that NK cells can acquire immunological memory with features that are classically associated with $\mathrm{T}$ and $\mathrm{B}$ cell responses is largely established by studying CMV infection in mice $(73,74)$ and humans $(61,62,75-78)$. In mice, MCMV infection induces the expansion of NK cells that express the activating receptor, $\mathrm{Ly} 49 \mathrm{H}$, which recognizes the viral protein m157 on the surface of infected cells $(74,79-81)$. $\mathrm{Ly}_{49 \mathrm{H}^{+}} \mathrm{NK}$ cells undergo marked expansion, followed by contraction, and establishment of a long-lived memory population that mounts a more effective protective response than naive NK cells against MCMV but not heterologous infections $(73,74,76)$. In humans, $\mathrm{CMV}$ infection induces an expansion of NK cells that express NKG2C $(75,76,82,83)$, an activating killer lectin-like receptor that binds HLA-E, which is upregulated by CMV UL40 protein $(84,85)$. These $\mathrm{NKG} 2 \mathrm{C}^{+}$memory NK cells are CD $56^{\text {dim }} \mathrm{CD} 57^{\text {bright }}$ and have a highly differentiated phenotype in regard to cytokine secretion and degranulation (75). They are preferentially negative for NKG2A $(76,82,83)$ and are biased toward the expression of self-specific "licensing" inhibitory KIRs: KIR2DL3 in $\mathrm{HLA}^{-\mathrm{Cl}^{+}}$ individuals and KIR2DL1 in HLA-C2 ${ }^{+}$individuals (76).

Similarly, in allogeneic HSCT, CMV reactivation is followed by an increase in the proportion of $\mathrm{NKG}_{2} \mathrm{C}^{+} \mathrm{NK}$ cells within $2-4$ weeks, which persists for at least a year $(86,87)$. These NK cells also have a more mature $\mathrm{NKG} 2 \mathrm{C}^{+} \mathrm{CD} 57^{+}$phenotype and are predominantly $\mathrm{KIR}^{+}$, especially for inhibitory self-KIRs (KIR2DL2/3), and secrete more IFN- $\gamma$ than NKG2C ${ }^{-}$NK cells $(67,87)$. CMV-seropositive recipients without overt CMV reactivation have an NK memory phenotype intermediate between patients with CMV reactivation and CMV-seronegative recipients, 
but only if they received a sibling allograft and not umbilical cord blood, which is generally considered to be CMV naive (67). This observation would suggest that donor NK memory could be transferrable. In support of this hypothesis, the same group had previously demonstrated that the $\mathrm{NKG}_{2} \mathrm{C}^{+} \mathrm{NK}$ cells that emerged following CMV reactivation had increased levels of IFN- $\gamma$ production when the donor was CMV seropositive rather than CMV seronegative (88). Furthermore, NK memory is undoubtedly transplantable in experimental mouse systems (74). The contribution of NK memory transfer in clinical allogeneic HSCT remains to be ascertained as NK reconstitution is primarily attributed to new NK cells generated from hematopoietic precursors rather than the expansion of NK cells from the graft, although this too remains to be conclusively demonstrated. NKG2C is not the only activating receptor relevant to $\mathrm{CMV}$ infection. CMV infection in healthy individuals also expands NK cells that express other activating receptors, including the activating KIRs: KIR2DS2 and KIR2DS4 (76). In allogeneic HSCT, recipients of umbilical cord blood transplant from donors with homozygous deletion of $N K G 2 C$, which represents $4 \%$ of the healthy population, have increased numbers of CD56 ${ }^{\mathrm{dim}} \mathrm{NKG} 2 \mathrm{~A}^{-}$ActivatingKIR ${ }^{+} \mathrm{NK}$ cells following CMV reactivation (69).

More recently, a distinct subset of FcR $\gamma$ (also known as FceRI $\gamma$ )deficient NK cells has been identified in CMV-seropositive individuals $(89,90)$. They are predominantly, but not exclusively, $\mathrm{NKG}_{2} \mathrm{C}^{+}$, and respond poorly to CMV-infected lung fibroblasts, but display enhanced antibody-dependent expansion, degranulation, and cytokine secretion $(61,90)$. FcR $\gamma$-deficient NK cells can be detected in some patients at 6-12 months after umbilical cord blood transplantation, but only if they had prior CMV reactivation (62). This memory-like FcR $\gamma^{-} \mathrm{NK}$ phenotype is the result of epigenetic modification with hypermethylation of the FCER1G promoter (62). Epigenetic silencing also results in a deficiency of the cell signaling proteins SYK and EAT-2, and transcription factors PLZF and IKZF2, within this population $(61,62)$. The significance of this newly described NK population in allogeneic HSCT remains to be investigated.

\section{IMPACT OF GVHD ON NK RECONSTITUTION}

Natural killer cell numbers were found to be lower in patients with acute and chronic GVHD $(16,91)$, but it is not known if these were casually related given the confounding effects of $\mathrm{T}$ cells, immunosuppression, and other clinical variables. On the other hand, acute GVHD is associated with the secretion of proinflammatory cytokines, for example, IL-12 and IL-18 (36), which are known to promote NK cell functional maturation. Acute GVHD is also associated with elevated levels of soluble ST2 (92), which serves as a decoy receptor to modulate the IL-33/ST2 axis

\section{REFERENCES}

1. Vivier E, Ugolini S. Natural killer cells: from basic research to treatments. Front Immunol (2011) 2:18. doi:10.3389/fimmu.2011.00018

2. Olson JA, Leveson-Gower DB, Gill S, Baker J, Beilhack A, Negrin RS. NK cells mediate reduction of GVHD by inhibiting activated, alloreactive T cells
$(93,94)$. This raises the possibility of effect on NK cells as IL-33/ ST2 axis augments NK cell production of IFN- $\gamma$ in response to IL-12 (95), and is important in MCMV-specific expansion of naive and memory Ly49H $\mathrm{H}^{+} \mathrm{NK}$ cells (96). At present, all these concepts remain speculative and require further investigation.

\section{INNATE LYMPHOID CELLS}

The lineage marker-negative innate lymphoid cells (ILCs) are a recently identified family of lymphoid cells that are preferentially located at barrier surfaces and can rapidly secrete immunoregulatory cytokines that correspond to the $\mathrm{T}_{\mathrm{H}} 1, \mathrm{~T}_{\mathrm{H}} 2$, or $\mathrm{T}_{\mathrm{H}} 17 / \mathrm{T}_{\mathrm{H}} 22$ immune response $(97,98)$. Their role in allogeneic HSCT is gradually being elucidated and it has been recently shown that recipient-derived intestinal ILCs are important in mediating protection from gut GVHD $(99,100)$. However, the nature and role of donor-derived ILC reconstitution remains largely unknown at present (101).

\section{CONCLUSION}

Natural killer cells reconstitute rapidly after HSCT but the delayed acquisition of a mature phenotype and functional competency argues for strategies to enhance functional NK cell reconstitution. These strategies can include adoptive transfer (102-104), with or without ex vivo expansion and cytokine activation (105, 106), graft engineering (20), donor selection according to KIR haplotype, and exogenous cytokine administration (107). Key unanswered questions relevant to optimizing NK-mediated anti-leukemic and anti-viral immunity include: what are the desired phenotypic characteristics of NK cells in this regard? What are the relative roles of unlicensed and licensed NK cells? Does NK cell memory contribute to long-term tumor immune surveillance? How are NK cells educated in HLA-mismatched transplantation and does this change over time? Additionally, what is the nature of ILC reconstitution post allogeneic HSCT? The answers to these questions are important in improving transplant outcome and further experimental and clinical studies are needed.

\section{AUTHOR CONTRIBUTIONS}

MU wrote the manuscript. GH conceptualized and edited the manuscript. S-KT conceptualized, wrote, and edited the manuscript.

\section{FUNDING}

$\mathrm{GH}$ is supported by an NHMRC SPR Fellowship and S-KT is supported by an NHMRC Early Career Fellowship.

while retaining GVT effects. Blood (2010) 115(21):4293-301. doi:10.1182/ blood-2009-05-222190

3. Asai O, Longo DL, Tian ZG, Hornung RL, Taub DD, Ruscetti FW, et al. Suppression of graft-versus-host disease and amplification of graft-versus-tumor effects by activated natural killer cells after allogeneic bone marrow transplantation. J Clin Invest (1998) 101(9):1835-42. doi:10.1172/JCI1268 
4. Yamasaki S, Henzan H, Ohno Y, Yamanaka T, Iino T, Itou Y, et al. Influence of transplanted dose of CD56+ cells on development of graft-versus-host disease in patients receiving G-CSF-mobilized peripheral blood progenitor cells from HLA-identical sibling donors. Bone Marrow Transplant (2003) 32(5):505-10. doi:10.1038/sj.bmt.1704165

5. Ruggeri L, Capanni M, Urbani E, Perruccio K, Shlomchik WD, Tosti A, et al. Effectiveness of donor natural killer cell alloreactivity in mismatched hematopoietic transplants. Science (2002) 295(5562):2097-100. doi:10.1126/ science. 1068440

6. Ruggeri L, Mancusi A, Capanni M, Urbani E, Carotti A, Aloisi T, et al. Donor natural killer cell allorecognition of missing self in haploidentical hematopoietic transplantation for acute myeloid leukemia: challenging its predictive value. Blood (2007) 110(1):433-40. doi:10.1182/blood-2006-07-038687

7. Velardi A, Ruggeri L, Mancusi A. Killer-cell immunoglobulin-like receptors reactivity and outcome of stem cell transplant. Curr Opin Hematol (2012) 19(4):319-23. doi:10.1097/MOH.0b013e32835423c3

8. Aversa F, Terenzi A, Tabilio A, Falzetti F, Carotti A, Ballanti S, et al. Full haplotype-mismatched hematopoietic stem-cell transplantation: a phase II study in patients with acute leukemia at high risk of relapse. J Clin Oncol (2005) 23(15):3447-54. doi:10.1200/JCO.2005.09.117

9. Ottinger HD, Beelen DW, Scheulen B, Schaefer UW, Grosse-Wilde H. Improved immune reconstitution after allotransplantation of peripheral blood stem cells instead of bone marrow. Blood (1996) 88(7):2775-9.

10. Shenoy S, Mohanakumar T, Todd G, Westhoff W, Dunnigan K, Adkins DR, et al. Immune reconstitution following allogeneic peripheral blood stem cell transplants. Bone Marrow Transplant (1999) 23(4):335-46. doi:10.1038/ sj.bmt. 1701581

11. Buhlmann L, Buser AS, Cantoni N, Gerull S, Tichelli A, Gratwohl A, et al. Lymphocyte subset recovery and outcome after T-cell replete allogeneic hematopoietic SCT. Bone Marrow Transplant (2011) 46(10):1357-62. doi:10.1038/bmt.2010.306

12. Brahmi Z, Hommel-Berrey G, Smith F, Thomson B. NK cells recover early and mediate cytotoxicity via perforin/granzyme and Fas/FasL pathways in umbilical cord blood recipients. Hum Immunol (2001) 62(8):782-90. doi:10.1016/S0198-8859(01)00275-0

13. Moretta A, Maccario R, Fagioli F, Giraldi E, Busca A, Montagna D, et al. Analysis of immune reconstitution in children undergoing cord blood transplantation. Exp Hematol (2001) 29(3):371-9. doi:10.1016/ S0301-472X(00)00667-6

14. Komanduri KV, St John LS, de Lima M, McMannis J, Rosinski S, McNiece I, et al. Delayed immune reconstitution after cord blood transplantation is characterized by impaired thymopoiesis and late memory T-cell skewing. Blood (2007) 110(13):4543-51. doi:10.1182/blood-2007-05-092130

15. Martinez C, Urbano-Ispizua A, Rozman C, Marin P, Rovira M, Sierra J, et al. Immune reconstitution following allogeneic peripheral blood progenitor cell transplantation: comparison of recipients of positive CD34+ selected grafts with recipients of unmanipulated grafts. Exp Hematol (1999) 27(3):561-8. doi:10.1016/S0301-472X(98)00029-0

16. Abrahamsen IW, Somme S, Heldal D, Egeland T, Kvale D, Tjonnfjord GE. Immune reconstitution after allogeneic stem cell transplantation: the impact of stem cell source and graft-versus-host disease. Haematologica (2005) 90(1):86-93.

17. Bjorklund AT, Schaffer M, Fauriat C, Ringden O, Remberger M, Hammarstedt C, et al. NK cells expressing inhibitory KIR for non-self-ligands remain tolerant in HLA-matched sibling stem cell transplantation. Blood (2010) 115(13):2686-94. doi:10.1182/blood-2009-07-229740

18. Cooley S, McCullar V, Wangen R, Bergemann TL, Spellman S, Weisdorf $\mathrm{DJ}$, et al. KIR reconstitution is altered by T cells in the graft and correlates with clinical outcomes after unrelated donor transplantation. Blood (2005) 106(13):4370-6. doi:10.1182/blood-2005-04-1644

19. Nguyen S, Kuentz M, Vernant JP, Dhedin N, Bories D, Debre P, et al. Involvement of mature donor $\mathrm{T}$ cells in the NK cell reconstitution after haploidentical hematopoietic stem-cell transplantation. Leukemia (2008) 22(2):344-52. doi:10.1038/sj.leu.2405041

20. Eissens DN, Schaap NP, Preijers FW, Dolstra H, van Cranenbroek B, Schattenberg AV, et al. CD3+/CD19+-depleted grafts in HLA-matched allogeneic peripheral blood stem cell transplantation lead to early NK cell cytolytic responses and reduced inhibitory activity of NKG2A. Leukemia (2010) 24(3):583-91. doi:10.1038/leu.2009.269
21. Yu J, Freud AG, Caligiuri MA. Location and cellular stages of natural killer cell development. Trends Immunol (2013) 34(12):573-82. doi:10.1016/j. it.2013.07.005

22. Nguyen S, Dhedin N, Vernant JP, Kuentz M, Al Jijakli A, Rouas-Freiss N, et al. NK-cell reconstitution after haploidentical hematopoietic stem-cell transplantations: immaturity of NK cells and inhibitory effect of NKG2A override GvL effect. Blood (2005) 105(10):4135-42. doi:10.1182/blood-2004-10-4113

23. Cooley S, Xiao F, Pitt M, Gleason M, McCullar V, Bergemann TL, et al. A subpopulation of human peripheral blood NK cells that lacks inhibitory receptors for self-MHC is developmentally immature. Blood (2007) 110(2):578-86. doi:10.1182/blood-2006-07-036228

24. Vago L, Forno B, Sormani MP, Crocchiolo R, Zino E, Di Terlizzi S, et al. Temporal, quantitative, and functional characteristics of single-KIR-positive alloreactive natural killer cell recovery account for impaired graft-versusleukemia activity after haploidentical hematopoietic stem cell transplantation. Blood (2008) 112(8):3488-99. doi:10.1182/blood-2007-07-103325

25. Dulphy N, Haas P, Busson M, Belhadj S, Peffault de Latour R, Robin M, et al. An unusual CD56(bright) CD16(low) NK cell subset dominates the early posttransplant period following HLA-matched hematopoietic stem cell transplantation. J Immunol (2008) 181(3):2227-37. doi:10.4049/ jimmunol.181.3.2227

26. Bjorkstrom NK, Riese P, Heuts F, Andersson S, Fauriat C, Ivarsson MA, et al. Expression patterns of NKG2A, KIR, and CD57 define a process of CD56dim NK-cell differentiation uncoupled from NK-cell education. Blood (2010) 116(19):3853-64. doi:10.1182/blood-2010-04-281675

27. Simonetta F, Pradier A, Bosshard C, Masouridi-Levrat S, Chalandon Y, Roosnek E. NK cell functional impairment after allogeneic hematopoietic stem cell transplantation is associated with reduced levels of T-bet and eomesodermin. JImmunol (2015) 195(10):4712-20. doi:10.4049/ jimmunol.1501522

28. Shilling HG, McQueen KL, Cheng NW, Shizuru JA, Negrin RS, Parham P. Reconstitution of NK cell receptor repertoire following HLA-matched hematopoietic cell transplantation. Blood (2003) 101(9):3730-40. doi:10.1182/ blood-2002-08-2568

29. Foley B, Cooley S, Verneris MR, Curtsinger J, Luo X, Waller EK, et al. NK cell education after allogeneic transplantation: dissociation between recovery of cytokine-producing and cytotoxic functions. Blood (2011) 118(10):2784-92. doi:10.1182/blood-2011-04-347070

30. Cooper MA, Fehniger TA, Caligiuri MA. The biology of human natural killer-cell subsets. Trends Immunol (2001) 22(11):633-40. doi:10.1016/ S1471-4906(01)02060-9

31. Jacobs R, Hintzen G, Kemper A, Beul K, Kempf S, Behrens G, et al. CD56bright cells differ in their KIR repertoire and cytotoxic features from CD56dim NK cells. Eur J Immunol (2001) 31(10):3121-7. doi:10.1002/1521-4141(2001010)31:10<3121::AID-IMMU3121>3.0.CO;2-4

32. Lazarevic V, Glimcher LH. T-bet in disease. Nat Immunol (2011) 12(7):597606. doi:10.1038/ni.2059

33. Gleason MK, Lenvik TR, McCullar V, Felices M, O’Brien MS, Cooley SA, et al. Tim-3 is an inducible human natural killer cell receptor that enhances interferon gamma production in response to galectin-9. Blood (2012) 119(13):3064-72. doi:10.1182/blood-2011-06-360321

34. Ndhlovu LC, Lopez-Verges S, Barbour JD, Jones RB, Jha AR, Long BR, et al. Tim-3 marks human natural killer cell maturation and suppresses cell-mediated cytotoxicity. Blood (2012) 119(16):3734-43. doi:10.1182/ blood-2011-11-392951

35. Fehniger TA, Cooper MA, Nuovo GJ, Cella M, Facchetti F, Colonna M, et al. CD56bright natural killer cells are present in human lymph nodes and are activated by T cell-derived IL-2: a potential new link between adaptive and innate immunity. Blood (2003) 101(8):3052-7. doi:10.1182/ blood-2002-09-2876

36. Nakamura H, Komatsu K, Ayaki M, Kawamoto S, Murakami M, Uoshima $\mathrm{N}$, et al. Serum levels of soluble IL-2 receptor, IL-12, IL-18, and IFN-gamma in patients with acute graft-versus-host disease after allogeneic bone marrow transplantation. J Allergy Clin Immunol (2000) 106(1 Pt 2):S45-50. doi:10.1067/mai.2000.106774

37. Shao-Hsien C, Lang I, Gunn H, Lydyard P. Effect of in vitro cyclosporin. A treatment on human natural and antibody-dependent cell-mediated cytotoxicity. Transplantation (1983) 35(2):127-9. doi:10.1097/00007890-198302000-00004 
38. Wang H, Grzywacz B, Sukovich D, McCullar V, Cao Q, Lee AB, et al. The unexpected effect of cyclosporin A on CD56+CD16- and CD56+CD16+ natural killer cell subpopulations. Blood (2007) 110(5):1530-9. doi:10.1182/ blood-2006-10-048173

39. LongEO, Kim HS, LiuD, Peterson ME, RajagopalanS. Controllingnaturalkiller cell responses: integration of signals for activation and inhibition. Annu Rev Immunol (2013) 31:227-58. doi:10.1146/annurev-immunol-020711-075005

40. Kim S, Poursine-Laurent J, Truscott SM, Lybarger L, Song YJ, Yang L, et al. Licensing of natural killer cells by host major histocompatibility complex class I molecules. Nature (2005) 436(7051):709-13. doi:10.1038/nature03847

41. Orr MT, Lanier LL. Natural killer cell education and tolerance. Cell (2010) 142(6):847-56. doi:10.1016/j.cell.2010.08.031

42. Anfossi N, Andre P, Guia S, Falk CS, Roetynck S, Stewart CA, et al. Human NK cell education by inhibitory receptors for MHC class I. Immunity (2006) 25(2):331-42. doi:10.1016/j.immuni.2006.06.013

43. Velardi A. Natural killer cell alloreactivity 10 years later. Curr Opin Hematol (2012) 19(6):421-6. doi:10.1097/MOH.0b013e3283590395

44. Haas P, Loiseau P, Tamouza R, Cayuela JM, Moins-Teisserenc H, Busson $M$, et al. NK-cell education is shaped by donor HLA genotype after unrelated allogeneic hematopoietic stem cell transplantation. Blood (2011) 117(3):1021-9. doi:10.1182/blood-2010-02-269381

45. Ruggeri L, Urbani E, Andre P, Mancusi A, Tosti A, Topini F, et al. Effects of anti-NKG2A antibody administration on leukemia and normal hematopoietic cells. Haematologica (2015). doi:10.3324/haematol.2015.135301

46. Reusing SB, Manser AR, Enczmann J, Mulder A, Claas FH, Carrington M, et al. Selective downregulation of HLA-C and HLA-E in childhood acute lymphoblastic leukaemia. Br J Haematol (2015). doi:10.1111/bjh.13777

47. Yu J, Venstrom JM, Liu XR, Pring J, Hasan RS, O’Reilly RJ, et al. Breaking tolerance to self, circulating natural killer cells expressing inhibitory KIR for non-self HLA exhibit effector function after T cell-depleted allogeneic hematopoietic cell transplantation. Blood (2009) 113(16):3875-84. doi:10.1182/ blood-2008-09-177055

48. Yokoyama WM, Kim S. Licensing of natural killer cells by self-major histocompatibility complex class I. Immunol Rev (2006) 214:143-54. doi:10.1111/j.1600-065X.2006.00458.x

49. Johansson MH, Bieberich C, Jay G, Karre K, Hoglund P. Natural killer cell tolerance in mice with mosaic expression of major histocompatibility complex class I transgene. J Exp Med (1997) 186(3):353-64. doi:10.1084/ jem.186.3.353

50. Fernandez NC, Treiner E, Vance RE, Jamieson AM, Lemieux S, Raulet DH. A subset of natural killer cells achieves self-tolerance without expressing inhibitory receptors specific for self-MHC molecules. Blood (2005) 105(11):4416-23. doi:10.1182/blood-2004-08-3156

51. Sun JC, Lanier LL. Cutting edge: viral infection breaks NK cell tolerance to "missing self". J Immunol (2008) 181(11):7453-7. doi:10.4049/ jimmunol.181.11.7453

52. Orr MT, Murphy WJ, Lanier LL. 'Unlicensed' natural killer cells dominate the response to cytomegalovirus infection. Nat Immunol (2010) 11(4):321-7. doi:10.1038/ni.1849

53. Biron CA, Nguyen KB, Pien GC, Cousens LP, Salazar-Mather TP. Natural killer cells in antiviral defense: function and regulation by innate cytokines. Annu Rev Immunol (1999) 17:189-220. doi:10.1146/annurev.immunol.17.1.189

54. Tarek N, Le Luduec JB, Gallagher MM, Zheng J, Venstrom JM, Chamberlain E, et al. Unlicensed NK cells target neuroblastoma following anti-GD2 antibody treatment. J Clin Invest (2012) 122(9):3260-70. doi:10.1172/JCI62749

55. Miller JS, Cooley S, Parham P, Farag SS, Verneris MR, McQueen KL, et al. Missing KIR ligands are associated with less relapse and increased graft-versus-host disease (GVHD) following unrelated donor allogeneic HCT. Blood (2007) 109(11):5058-61. doi:10.1182/blood-2007-01-065383

56. Hsu KC, Keever-Taylor CA, Wilton A, Pinto C, Heller G, Arkun K, et al. Improved outcome in HLA-identical sibling hematopoietic stem-cell transplantation for acute myelogenous leukemia predicted by KIR and HLA genotypes. Blood (2005) 105(12):4878-84. doi:10.1182/blood-2004-12-4825

57. Ruggeri L, Capanni M, Casucci M, Volpi I, Tosti A, Perruccio K, et al. Role of natural killer cell alloreactivity in HLA-mismatched hematopoietic stem cell transplantation. Blood (1999) 94(1):333-9.

58. Joncker NT, Shifrin N, Delebecque F, Raulet DH. Mature natural killer cells reset their responsiveness when exposed to an altered MHC environment. J Exp Med (2010) 207(10):2065-72. doi:10.1084/jem.20100570
59. Elliott JM, Wahle JA, Yokoyama WM. MHC class I-deficient natural killer cells acquire a licensed phenotype after transfer into an MHC class I-sufficient environment. J Exp Med (2010) 207(10):2073-9. doi:10.1084/ jem.20100986

60. Shifrin N, Raulet DH, Ardolino M. NK cell self tolerance, responsiveness and missing self recognition. Semin Immunol (2014) 26(2):138-44. doi:10.1016/j. smim.2014.02.007

61. Lee J, Zhang T, Hwang I, Kim A, Nitschke L, Kim M, et al. Epigenetic modification and antibody-dependent expansion of memory-like NK cells in human cytomegalovirus-infected individuals. Immunity (2015) 42(3):431-42. doi:10.1016/j.immuni.2015.02.013

62. Schlums H, Cichocki F, Tesi B, Theorell J, Beziat V, Holmes TD, et al. Cytomegalovirus infection drives adaptive epigenetic diversification of NK cells with altered signaling and effector function. Immunity (2015) 42(3):443-56. doi:10.1016/j.immuni.2015.02.008

63. Luetke-Eversloh M, Hammer Q, Durek P, Nordstrom K, Gasparoni G, Pink $\mathrm{M}$, et al. Human cytomegalovirus drives epigenetic imprinting of the IFNG locus in NKG2Chi natural killer cells. PLoS Pathog (2014) 10(10):e1004441. doi:10.1371/journal.ppat.1004441

64. Suessmuth Y, Mukherjee R, Watkins B, Koura DT, Finstermeier K, Desmarais $\mathrm{C}$, et al. CMV reactivation drives posttransplant T-cell reconstitution and results in defects in the underlying TCRbeta repertoire. Blood (2015) 125(25):3835-50. doi:10.1182/blood-2015-03-631853

65. Knight A, Madrigal AJ, Grace S, Sivakumaran J, Kottaridis P, Mackinnon S, et al. The role of Vdelta2-negative gammadelta T cells during cytomegalovirus reactivation in recipients of allogeneic stem cell transplantation. Blood (2010) 116(12):2164-72. doi:10.1182/blood-2010-01-255166

66. Scheper W, van Dorp S, Kersting S, Pietersma F, Lindemans C, Hol S, et al. gammadeltaT cells elicited by CMV reactivation after allo-SCT cross-recognize CMV and leukemia. Leukemia (2013) 27(6):1328-38. doi:10.1038/ leu.2012.374

67. Davis ZB, Cooley SA, Cichocki F, Felices M, Wangen R, Luo X, et al. Adaptive natural killer cell and killer cell immunoglobulin-like receptor-expressing $\mathrm{T}$ cell responses are induced by cytomegalovirus and are associated with protection against cytomegalovirus reactivation after allogeneic donor hematopoietic cell transplantation. Biol Blood Marrow Transplant (2015) 21(9):1653-62. doi:10.1016/j.bbmt.2015.05.025

68. Itzykson R, Robin M, Moins-Teisserenc H, Delord M, Busson M, Xhaard A, et al. Cytomegalovirus shapes long-term immune reconstitution after allogeneic stem cell transplantation. Haematologica (2015) 100(1):114-23. doi:10.3324/haematol.2014.113415

69. Della Chiesa M, Falco M, Bertaina A, Muccio L, Alicata C, Frassoni F, et al. Human cytomegalovirus infection promotes rapid maturation of NK cells expressing activating killer Ig-like receptor in patients transplanted with NKG2C-/- umbilical cord blood. J Immunol (2014) 192(4):1471-9. doi:10.4049/jimmunol.1302053

70. Horowitz A, Guethlein LA, Nemat-Gorgani N, Norman PJ, Cooley S, Miller JS, et al. Regulation of adaptive NK cells and CD8 T cells by HLA-C correlates with allogeneic hematopoietic cell transplantation and with cytomegalovirus reactivation. J Immunol (2015) 195(9):4524-36. doi:10.4049/ jimmunol.1401990

71. Green ML, Leisenring WM, Xie H, Walter RB, Mielcarek M, Sandmaier BM, et al. CMV reactivation after allogeneic HCT and relapse risk: evidence for early protection in acute myeloid leukemia. Blood (2013) 122(7):1316-24. doi:10.1182/blood-2013-02-487074

72. Elmaagacli AH, Steckel NK, Koldehoff M, Hegerfeldt Y, Trenschel R, Ditschkowski M, et al. Early human cytomegalovirus replication after transplantation is associated with a decreased relapse risk: evidence for a putative virus-versus-leukemia effect in acute myeloid leukemia patients. Blood (2011) 118(5):1402-12. doi:10.1182/blood-2010-08-304121

73. Min-Oo G, Lanier LL. Cytomegalovirus generates long-lived antigen-specific NK cells with diminished bystander activation to heterologous infection. J Exp Med (2014) 211(13):2669-80. doi:10.1084/jem.20141172

74. Sun JC, Beilke JN, Lanier LL. Adaptive immune features of natural killer cells. Nature (2009) 457(7229):557-61. doi:10.1038/nature07665

75. Beziat V, Dalgard O, Asselah T, Halfon P, Bedossa P, Boudifa A, et al. CMV drives clonal expansion of NKG2C+ NK cells expressing self-specific KIRs in chronic hepatitis patients. Eur J Immunol (2012) 42(2):447-57. doi:10.1002/ eji.201141826 
76. Beziat V, Liu LL, Malmberg JA, Ivarsson MA, Sohlberg E, Bjorklund AT, et al. NK cell responses to cytomegalovirus infection lead to stable imprints in the human KIR repertoire and involve activating KIRs. Blood (2013) 121(14):2678-88. doi:10.1182/blood-2012-10-459545

77. Della Chiesa M, Sivori S, Carlomagno S, Moretta L, Moretta A. Activating KIRs and NKG2C in viral infections: toward NK Cell Memory? Front Immunol (2015) 6:573. doi:10.3389/fimmu.2015.00573

78. O'Sullivan TE, Sun JC, Lanier LL. Natural killer cell memory. Immunity (2015) 43(4):634-45. doi:10.1016/j.immuni.2015.09.013

79. Arase H, Mocarski ES, Campbell AE, Hill AB, Lanier LL. Direct recognition of cytomegalovirus by activating and inhibitory NK cell receptors. Science (2002) 296(5571):1323-6. doi:10.1126/science.1070884

80. Daniels KA, Devora G, Lai WC, O’Donnell CL, Bennett M, Welsh RM. Murine cytomegalovirus is regulated by a discrete subset of natural killer cells reactive with monoclonal antibody to Ly49H. JExp Med (2001) 194(1):29-44. doi:10.1084/jem.194.1.29

81. Smith HR, Heusel JW, Mehta IK, Kim S, Dorner BG, Naidenko OV, et al. Recognition of a virus-encoded ligand by a natural killer cell activation receptor. Proc Natl Acad Sci USA (2002) 99(13):8826-31. doi:10.1073/ pnas.092258599

82. Lopez-Verges S, Milush JM, Schwartz BS, Pando MJ, Jarjoura J, York VA, et al. Expansion of a unique CD57(+)NKG2Chi natural killer cell subset during acute human cytomegalovirus infection. Proc Natl Acad Sci USA (2011) 108(36):14725-32. doi:10.1073/pnas.1110900108

83. Guma M, Angulo A, Vilches C, Gomez-Lozano N, Malats N, LopezBotet M. Imprint of human cytomegalovirus infection on the NK cell receptor repertoire. Blood (2004) 104(12):3664-71. doi:10.1182/ blood-2004-05-2058

84. Pietra G, Romagnani C, Mazzarino P, Falco M, Millo E, Moretta A, et al. HLA-E-restricted recognition of cytomegalovirus-derived peptides by human CD8+ cytolytic T lymphocytes. Proc Natl Acad Sci USA (2003) 100(19):10896-901. doi:10.1073/pnas.1834449100

85. Della Chiesa M, Falco M, Muccio L, Bertaina A, Locatelli F, Moretta A. Impact of HCMV infection on NK cell development and function after HSCT. Front Immunol (2013) 4:458. doi:10.3389/fimmu.2013.00458

86. Della Chiesa M, Falco M, Podesta M, Locatelli F, Moretta L, Frassoni F, et al. Phenotypic and functional heterogeneity of human NK cells developing after umbilical cord blood transplantation: a role for human cytomegalovirus? Blood (2012) 119(2):399-410. doi:10.1182/blood-2011-08-372003

87. Foley B, Cooley S, Verneris MR, Pitt M, Curtsinger J, Luo X, et al. Cytomegalovirus reactivation after allogeneic transplantation promotes a lasting increase in educated NKG2C+ natural killer cells with potent function. Blood (2012) 119(11):2665-74. doi:10.1182/blood-2011-10-386995

88. Foley B, Cooley S, Verneris MR, Curtsinger J, Luo X, Waller EK, et al. Human cytomegalovirus (CMV)-induced memory-like $\mathrm{NKG} 2 \mathrm{C}(+) \mathrm{NK}$ cells are transplantable and expand in vivo in response to recipient CMV antigen. J Immunol (2012) 189(10):5082-8. doi:10.4049/jimmunol.1201964

89. Hwang I, Zhang T, Scott JM, Kim AR, Lee T, Kakarla T, et al. Identification of human NK cells that are deficient for signaling adaptor FcRgamma and specialized for antibody-dependent immune functions. Int Immunol (2012) 24(12):793-802. doi:10.1093/intimm/dxs080

90. Zhang T, Scott JM, Hwang I, Kim S. Cutting edge: antibody-dependent memory-like NK cells distinguished by FcRgamma deficiency. J Immunol (2013) 190(4):1402-6. doi:10.4049/jimmunol.1203034

91. Kheav VD, Busson M, Scieux C, Peffault de Latour R, Maki G, Haas P, et al. Favorable impact of natural killer cell reconstitution on chronic graftversus-host disease and cytomegalovirus reactivation after allogeneic hematopoietic stem cell transplantation. Haematologica (2014) 99(12):1860-7. doi:10.3324/haematol.2014.108407

92. Vander Lugt MT, Braun TM, Hanash S, Ritz J, Ho VT, Antin JH, et al. ST2 as a marker for risk of therapy-resistant graft-versus-host disease and death. N Engl J Med (2013) 369(6):529-39. doi:10.1056/NEJMoa1213299
93. Reichenbach DK, Schwarze V, Matta BM, Tkachev V, Lieberknecht E, Liu Q, et al. The IL-33/ST2 axis augments effector T-cell responses during acute GVHD. Blood (2015) 125(20):3183-92. doi:10.1182/blood-2014-10-606830

94. Zhang J, Ramadan AM, Griesenauer B, Li W, Turner MJ, Liu C, et al. ST2 blockade reduces sST2-producing $\mathrm{T}$ cells while maintaining protective mST2-expressing T cells during graft-versus-host disease. Sci Transl Med (2015) 7(308):308ra160. doi:10.1126/scitranslmed.aab0166

95. Bourgeois E, Van LP, Samson M, Diem S, Barra A, Roga S, et al. The pro-Th2 cytokine IL-33 directly interacts with invariant NKT and NK cells to induce IFN-gamma production. Eur J Immunol (2009) 39(4):1046-55. doi:10.1002/ eji.200838575

96. Nabekura T, Girard JP, Lanier LL. IL-33 receptor ST2 amplifies the expansion of NK cells and enhances host defense during mouse cytomegalovirus infection. J Immunol (2015) 194(12):5948-52. doi:10.4049/jimmunol.1500424

97. Hazenberg MD, Spits H. Human innate lymphoid cells. Blood (2014) 124(5):700-9. doi:10.1182/blood-2013-11-427781

98. Walker JA, Barlow JL, McKenzie ANJ. Innate lymphoid cells-how did we miss them? Nat Rev Immunol (2013) 13(2):75-87. doi:10.1038/nri3349

99. Hanash AM, Dudakov JA, Hua G, O'Connor MH, Young LF, Singer NV, et al. Interleukin-22 protects intestinal stem cells from immune-mediated tissue damage and regulates sensitivity to graft versus host disease. Immunity (2012) 37(2):339-50. doi:10.1016/j.immuni.2012.05.028

100. Konya V, Mjosberg J. Innate lymphoid cells in graft-versus-host disease. Am J Transplant (2015) 15(11):2795-801. doi:10.1111/ajt.13394

101. Munneke JM, Bjorklund AT, Mjosberg JM, Garming-Legert K, Bernink JH, Blom B, et al. Activated innate lymphoid cells are associated with a reduced susceptibility to graft-versus-host disease. Blood (2014) 124(5):812-21. doi:10.1182/blood-2013-11-536888

102. Cichocki F, Verneris MR, Cooley S, Bachanova V, Brunstein CG, Blazar BR, et al. The past, present, and future of NK cells in hematopoietic cell transplantation and adoptive transfer. Curr Top Microbiol Immunol (2016) 395:225-43. doi:10.1007/82_2015_445

103. Miller JS, Soignier Y, Panoskaltsis-Mortari A, McNearney SA, Yun GH, Fautsch SK, et al. Successful adoptive transfer and in vivo expansion of human haploidentical NK cells in patients with cancer. Blood (2005) 105(8):3051-7. doi:10.1182/blood-2004-07-2974

104. Ruggeri L, Parisi S, Urbani E, Curti A. Alloreactive natural killer cells for the treatment of acute myeloid leukemia: from stem cell transplantation to adoptive immunotherapy. Front Immunol (2015) 6:479. doi:10.3389/ fimmu.2015.00479

105. Huber CM, Doisne JM, Colucci F. IL-12/15/18-preactivated NK cells suppress GvHD in a mouse model of mismatched hematopoietic cell transplantation. Eur J Immunol (2015) 45(6):1727-35. doi:10.1002/eji.201445200

106. Shah NN, Baird K, Delbrook CP, Fleisher TA, Kohler ME, Rampertaap S, et al. Acute GVHD in patients receiving IL-15/4-1BBL activated NK cells following T-cell-depleted stem cell transplantation. Blood (2015) 125(5):784-92. doi:10.1182/blood-2014-07-592881

107. Bachanova V, Cooley S, Defor TE, Verneris MR, Zhang B, McKenna DH, et al. Clearance of acute myeloid leukemia by haploidentical natural killer cells is improved using IL-2 diphtheria toxin fusion protein. Blood (2014) 123(25):3855-63. doi:10.1182/blood-2013-10-532531

Conflict of Interest Statement: The authors declare that the research was conducted in the absence of any commercial or financial relationships that could be construed as a potential conflict of interest.

Copyright (C) 2016 Ullah, Hill and Tey. This is an open-access article distributed under the terms of the Creative Commons Attribution License (CC BY). The use, distribution or reproduction in other forums is permitted, provided the original author(s) or licensor are credited and that the original publication in this journal is cited, in accordance with accepted academic practice. No use, distribution or reproduction is permitted which does not comply with these terms. 